\title{
Trapping of hydrogen in metallic materials
}

\author{
Hiroshi SUZUKI*
}

Keywords: hydrogen; trapping mechanism; binding energy; thermal desorption analysis

本解説では, 水素の材料中でのトラップについて, その機 構や昇温脱離試験による実験的解析方法, 計算科学による解 析について説明する。材料中の水素の状態やトラップ挙動に ついては, 優れた教科書 $\left.{ }^{1)}, 2\right)$ や解説 ${ }^{3)}$,4) がある。これらの 文献では, 水素の存在による特性の低下や破壊の促進として 現れる水素脆性が歴史的に大きな問題である，鉄鋼や $\mathrm{Ni}$ 系 材料等を例として説明されることが多いが，本稿ではアルミ ニウム（Al）とその合金を中心に解説する。

\section{1. 材料中での水素の状態}

環境からの水素の侵入と材料中での移動について，金属／ 水素系の外部 · 表面 · 内部のポテンシャルエネルギーの変化 は図1のように考えられている。この図は Christmann ${ }^{5)}$ が概 念を示した水素の材料表面への吸着および侵入に伴うポテン

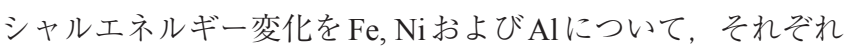
の物性值に基づいて横川 ${ }^{6)}$ が描いたものである。図中, 金 属表面から無限遠にかけてのポテンシャルエネルギーの変化 は, 無限遠で 0 となる水素分子 $\mathrm{H}_{2}$ と, 解離エネルギーに相当 する值まで徐々に上昇する原子 $2 \mathrm{H}$ の両方が示されているが, 水素は分子として近づいて表面に物理吸着し, 次いで化学吸 着する。 $\mathrm{Fe}, \mathrm{Ni}$ では物理吸着によるポテンシャル低下は小さ いが，化学吸着により大きく低下する。水素が材料中に侵入 するにはこの低下分を超える必要があり，いったん侵入した 後には原子間のポテンシャル場の変動を超えながら内部へ拡 散し, 欠陥にトラップされて再びエネルギーが低下し, 安定 に存在する。これに比較して $\mathrm{Al}$ では物理吸着が難しく, 化 学吸着もポテンシャルが高いことから水素は固溶しにくく, 材料内部に侵入した後も活性化エネルギーが高いことからト ラップサイトに安定しない。結果として水素は材料中に存在 するよりも外部に放散されやすいことが図より理解できる。 このような違いが $\mathrm{Al}$ での水素吸蔵および水素脆化が Fe や Ni と異なることの原因であることを横川は示唆している。

\section{Al中のトラップサイト}

南雲 ${ }^{1)}$ は, 「欠陥のまわりで水素原子のポテンシャルエネ
ルギーが正規結晶中の固溶状態に比べて低い時には, 水素が 欠陥のまわりに存在する確率が高く, 水素原子は欠陥に捕 獲（トラップ）されているという」と水素のトラップを定義 している。格子間原子としてとどまる場合のセルフトラッ プ状態の電子論については深井 ${ }^{7)}$ が詳細に記述しているが, 水素の存在により力学特性を中心とした特性が変化すること を論じるときには，欠陥にトラップされる場合を考えること が多い。それぞれの欠陉と水素の結合エネルギーにより卜 ラップの強さは異なるが, 異なる種類の欠陥を有する材料 中では，平衡状態であれば水素はFermi-Dirac 統計に従って， より強く水素をトラップする欠陷に優先的に分布し，各卜 ラップでの水素濃度は温度や結合エネルギーにより決まる。

水素と化合物を作る $\mathrm{Ti}$ などでなければ，金属一水素系の状 態図から予測される水素の固溶限は通常極めて少なく, 室温 近傍ではごく低い值となる。 $\mathrm{Al}$ がこれに相当するが，この 点ではFeや Ni も同様である。しかし, 製造された材料の水 素量は分析するとそれよりもずっと多く, 水素は材料中の欠 陥にトラップされて存在していると考えられている。

南雲 ${ }^{8)}$ は, 鋼を念頭に置いて, 水素のトラップサイトを 固溶状態, 転位, 空孔, 析出物, 結晶粒界, 内部き裂・ボイ ドと分類し, それぞれについて実例やトラップの機構を解説 している。図2に材料中のトラップサイトの概略図として, 横川 ${ }^{6)}$ が材料の脆化機構とのかかわりを含んで描いた図を 示す。

伊藤ら ${ }^{9)}$ は $\mathrm{Al}$ でのトラップを検討し，トラップサイトを 固溶 (母相内) , 転位, 水和酸化被膜中, 酸化被膜 / 金属界面, 結晶粒界, ポロシティ, 第二相内, 第二相 /母相界面, ナノ ボイド (空孔集合体) と分類し, 図 2 と類似な $\mathrm{A} 1$ で考えられ

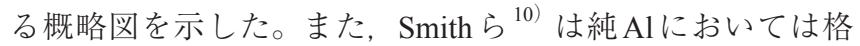
子間位置, 転位, 空孔, $\mathrm{A} 1$ 合金では GPゾーン, 安定あるい は不安定な析出物, 高傾角粒界をトラップサイトとしてあげ ている。Ichimura $~^{11)} も 4 \mathrm{~N}-\mathrm{Al}$ 中の水素の拡散に与える粒 界の影響を測定した報告において, 考えられる $\mathrm{Al}$ 中の水素 のトラップサイトのリストを示している。また, Hebert ${ }^{12)}$ は 腐食に伴って $\mathrm{Al}$ 中に吸蔵され，トラップされる水素につい

\footnotetext{
* 上智大学理工学部（广102-8554 東京都千代田区紀尾井町 7-1） Faculty of Science and Technology, Sophia University (7-1 Kioicho, Chiyoda-ku, Tokyo 102-8554) E-mail: h-suzuki@sophia.ac.jp

受付日：平成 30 年 6 月 30 日 受理日：平成 30 年 8 月 2 日
} 


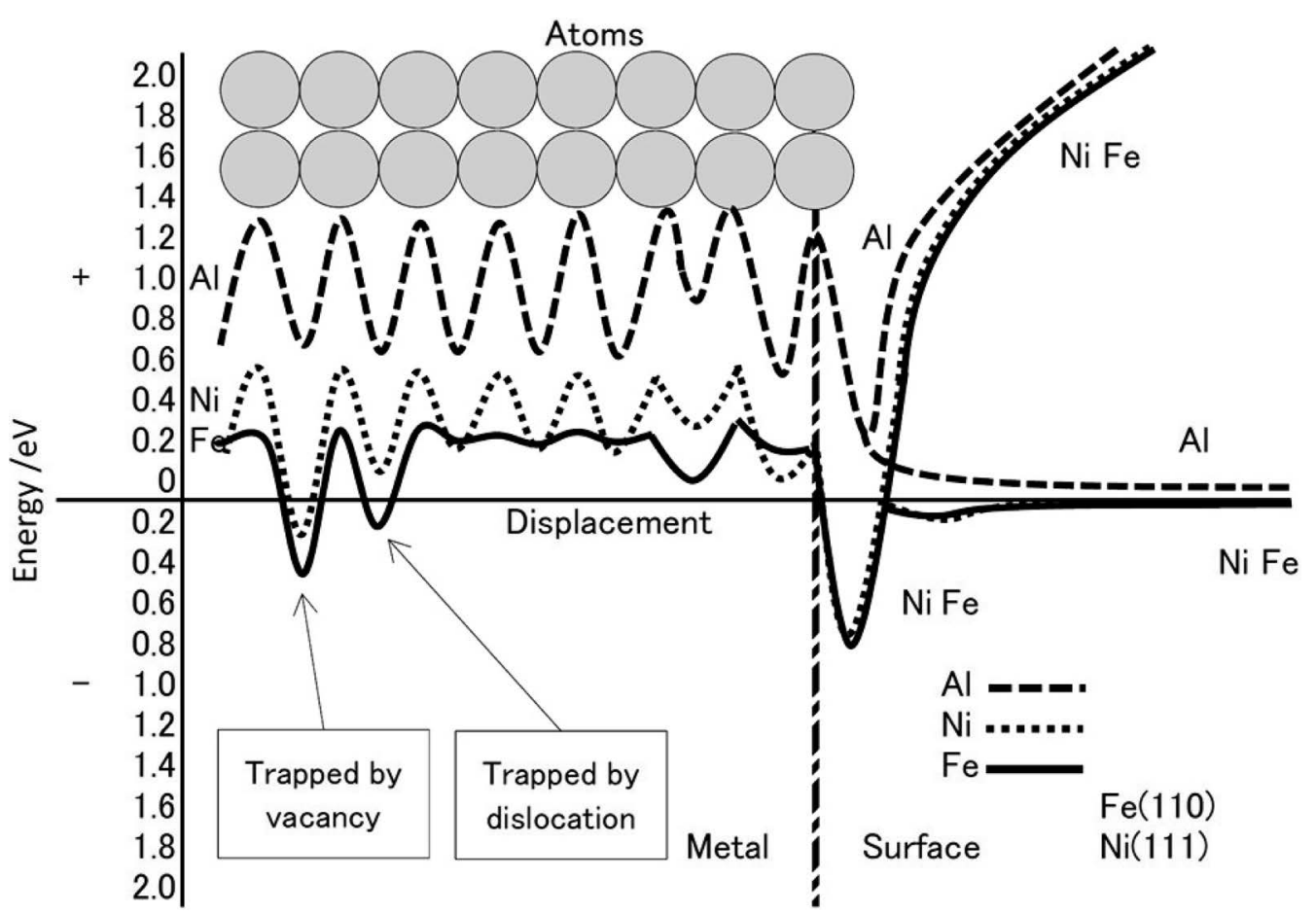

図 1 金属 / 水素系のポテンシャルエネルギー図 ${ }^{6)}$

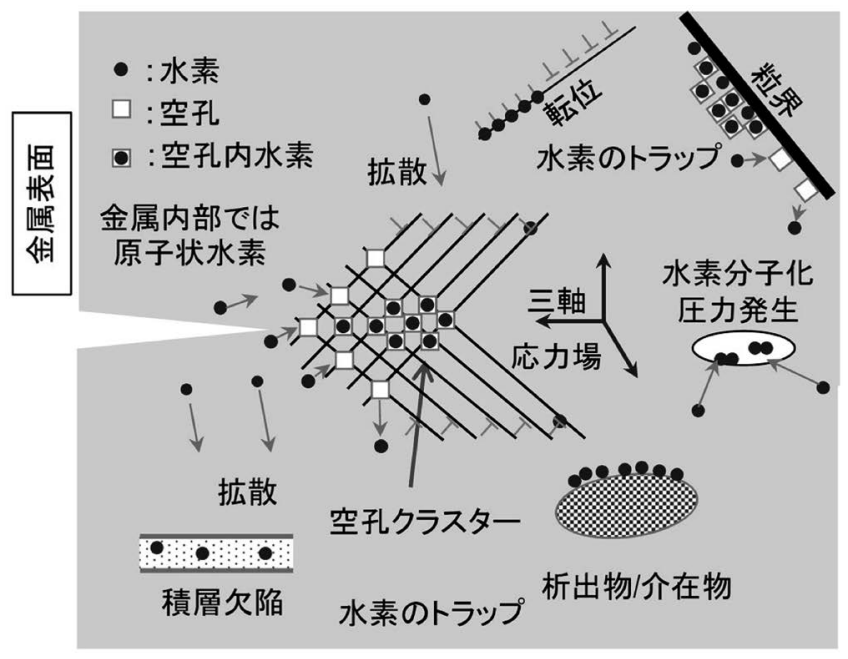

図2 金属材料内部での水素の状態とトラップ 6)

て，モデルに基づいて検討している。

鋼と $\mathrm{Al}$ を比較すると, $\mathrm{Al}$ で水素の材料中でのトラップを 考える場合は，表面酸化物を考慮する必要があること，製造 時のポロシティあるいはマイクロポアを考慮するべきこと, さらに析出物およびその界面が重要な要素となることを考慮 しなければならないことが理解できる。

また， $\mathrm{A} 1$ への外部からの水素の侵入は空孔の生成を伴う ことが数多く報告されて抢り， $\mathrm{Al}$ 中の水素を考える際には 空孔や，それが集合することにより生じるポアが重要である と考えられる。Hashimotoら ${ }^{13)}$ は高温で水素ガス環境, 室温 で電気化学チャージにより $6 \mathrm{~N}-\mathrm{Al}$ に対して水素透過試験を行 い，拡散の活性化エネルギーを求めるとともに， $\mathrm{Al}$ では水 素の侵入に伴って多量の空孔が生じ, 水素と空孔が結合して 移動することを示唆した。

Birnbaum ら ${ }^{14)}$ は化学的方法, 電気化学的方法, プラズ
マ, 超音波など, 様々な方法での水素添加を試し, 最大 $2000 \mathrm{appm}$ の水素添加が可能であることを示した。このとき, 試料の寸法の変化を測定し, 通常の金属材料で水素の吸蔵に 伴って生じる体積増加が見られないことから, 侵入した水素 は空孔と対を形成しているものと推測した。また, 中性子散 乱により, 空孔は（111）方向に延びた構造を示すことも報 告している ${ }^{15)}$ 。Scammans ${ }^{16)}$ は $\mathrm{Al}-\mathrm{Zn}-\mathrm{Mg}$ 合金の水素脆化を 測定し, 同様に水素が $\{111\}$ 面に沿うレンズ状のバブル中に 析出することを観察し, これらが粒界析出物と関係して脆化 を引き起こすとした。Paskeviciusら ${ }^{17)}$ は, 水素吸蔵に伴っ て生じるバブル径を測定した。Tanguy ${ }^{18)}$ はモンテカルロ 法で $\mathrm{Al}$ 中での水素の挙動をシミュレートし, 水素濃度 $1 \%$ のとき, 空孔-2水素対および空孔-3水素対のクラスターが $\langle 110\rangle$ チェインを形成し, $\{111\}$ および $\{110\}$ 小板が生じると する結果を得た。

同様にAdhikari ら ${ }^{19)}$ はアルカリ環境中でPdを表面に蒸着 した $\mathrm{A} 1$ 中に水素が急速に吸蔵されることを示し，これを水 素ー空孔対の生成によるとした。

堀川ら ${ }^{20)}$ は, 粒界への水素の集積を報告している。また, 製造時に生じたポロシティに分子状の水素として存在する ことは古くから知られているが，Toda ${ }^{21)}$ は高純度の $\mathrm{Al}$ と $\mathrm{Mg}$ を原料として製造し, 製造時の環境を変えることで水素 量を変化させた $\mathrm{Al}-5.5 \% \mathrm{Mg}$ 合金中のポロシティの高温での 変化と, それにあわせて析出物を加速器からの高エネルギー $\mathrm{X}$ 線源によるX線 $\mu$-CTにより直接観察し, ポロシティ中の 水素量を推測するとともに, 析出物との関係を明らかにし た。その結果, 同合金ではポロシティが水素の主たるトラッ プサイトであることを確認し, あわせて同等の水素量の高純 度 $\mathrm{Al}$ に対する同様の観測によりポロシティ中の水素量が少 ないことから, ポロシティに水素がトラップされるためには 析出物の存在が必要であることを示唆した。

Itoh ${ }^{22)}$ は4 $\mathrm{N}-\mathrm{Al}$ に対するオートラジオグラフィーによ 
り，変形に伴って転位が水素を輸送することを確認した。ま た, 堀川ら ${ }^{23)}$ は $\mathrm{Al}-\mathrm{Mg}-\mathrm{Si}$ 合金疲労試験中の水素放出を水素 マイクロプリント法により測定した。転位により水素がト ラップされて輸送され，表面のすべり帯に集積することが認 められた。これらを例として, 転位が水素のトラップサイト であることに対する多くの報告がある。

\section{3. トラップサイトの同定と昇温脱離試験}

$\mathrm{Hirth}^{3)}$ は水素が鋼の特性に与える影響をまとめた総説に おいて，トラップサイトとして水素をトラップする欠陥と， それらとの結合エネルギーを表として示した。鉄鋼材料では 古くから水素の与える影響の研究が進んでおり, 様々な手法 によって求められたエネルギー值が報告され，欠陥の種類ご との值についてはほぼ合意があり，それに基づいてトラップ サイトが解析されている。

トラップサイトへの結合エネルギーは，拡散の測定や内部 摩擦計測法, 電気抵抗法, 水素透過試験等により測定されて きた。近年では, 昇温脱離試験により評価されることが多い。

昇温脱離試験は，元は表面分析技術であったが，金属材料 中の水素のトラップ状態を研究する手法として広く使われる ようになった ${ }^{24)}$ 。この試験では不活性ガスあるいは高真空 中で試料を一定速度で昇温して加熱し，放出される水素を不 活性ガスの場合はガスクロマトグラフ，真空中では四重極質 量分析機で検出して水素放出プロファイルを得る。プロファ イル上に現れる1つまたは複数のピークはそれぞれが異なる 水素との結合エネルギーを持つトラップサイトに対応するこ とから，トラップサイトの同定ができ，プロファイルの曲線 の下側面積によりトラップの量の見積りもできる。

さらに, 昇温速度 $\Phi$ を変化させてピーク温度 $T_{\mathrm{p}}$ を測定し,

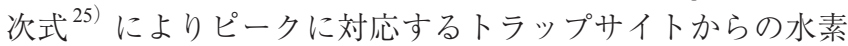
解離エネルギー $E_{\mathrm{a}}$ が求まる。 $E_{\mathrm{a}}$ から固溶状態へ移る鞍点エ ネルギーを引いた值が結合エネルギーである。

$$
\frac{\partial\left[\ln \left(\Phi / T_{\mathrm{p}}^{2}\right)\right]}{\partial\left(1 / T_{\mathrm{p}}\right)}=-\frac{E_{\mathrm{a}}}{R}
$$

鉄鋼材料では昇温脱離試験より求まる結合エネルギーと 他の方法で求まった值とは通常よい一致を示し，信頼性の 高い方法として認められている。また，水素脆性に影響を
与える欠陥の種類や量を同定する手法として, 試料に水素を 吸蔵させてトラップサイトに水素を配置し, 昇温脱離試験に より水素放出プロファイルを測定して，水素をトレーサーと して使う“トレーサー水素法”は, 空孔型欠陥や転位への水 素のトラップの定性的・定量的評価に対して成果をあげてい る $^{26), 27)}$ 。

しかしながら，Alでは昇温脱離試験の報告例は多くなく， かつ水素放出特性の報告ごとの整合性にそしいことから，結 合エネルギーの測定方法として確立されているとはいえな い。

鉄鋼材料では水素を材料に添加する方法について, ガス チャージ, 浸漬法, 電気化学的方法などが使われている。こ のような方法で添加された水素が実環境で材料中に侵入する 水素とまったく同じものであるかについては議論の余地があ るとされているが, 少なくとも実験条件を適切に設定するこ とにより添加する水素量を制御することができ，また水素添 加に伴う組織変化はほとんどないという共通の認識がある。 これに対して， $\mathrm{Al}$ とその合金では，本稿の始めで述べたよ うに，そもそも水素が侵入しにくいこと，材料表面での化学 吸着に伴うエネルギー低下が大きいことなどから，水素を精

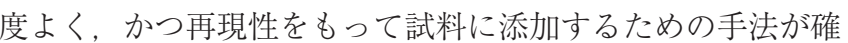
立しているとはいえない。ひとつの原因としては $\mathrm{Al}$ 表面の 酸化被膜の存在があげられる。また，先に述べたように，Al では水素の侵入に伴って水素量に匹敵, あるいはそれを超え る濃度の空孔が導入されるとの実験報告が多数なされてい る。すなわち人工的な水素吸蔵に伴って微細組織が変化する 可能性がある。また, 鉄鋼材料において水素添加法として広 く一般的に使われる電気化学的方法（電解水素チャージ）を $\mathrm{Al}$ に対して適用した場合, 表面の腐食生成物の制御が問題 となる。

\section{4. $\mathrm{Al}$ に対する昇温脱離試験の報告例と水素トラッ プサイトの同定の試み}

$\mathrm{Al}$ とその合金に対する昇温脱離試験の報告例を時系列 により表 1 によめる。これらのうち, Young ${ }^{28)}$ および Izumi ${ }^{29)}$ による報告がよく参照される。Young ${ }^{28)}$ は直 径 $2 \mathrm{~mm}$ の純度 $5 \mathrm{~N}$ の $\mathrm{Al}$ 線を $90^{\circ} \mathrm{C}$ の湿潤環境中に $48 \mathrm{~h}$ 置いて 水素を吸蔵させ, 高真空中で昇温速度 $600^{\circ} \mathrm{C} / \mathrm{h}$ で加熱し, 四

表 $1 \mathrm{Al}$ およびその合金に対する昇温脱離分析の報告例

\begin{tabular}{|c|c|c|c|}
\hline 報告 & 材料 & 水素添加条件 & 測定方法 \\
\hline 広畑, 1992 & $4 \mathrm{~N}-\mathrm{Al}$ & 製造時 & 質量分析器 \\
\hline Young, $1998^{28)}$ & $6 \mathrm{~N}-\mathrm{Al}$ & 湿潤環境 & 質量分析器 \\
\hline Hayashi, $1998^{37)}$ & 単結晶 $6 \mathrm{~N}-\mathrm{Al}, \mathrm{Al}-1000 \mathrm{ppmSi}$ & 水中研磨 & 質量分析器 \\
\hline Smith, $2000^{30)}$ & $\mathrm{Al}-\mathrm{Li}$ & 電解チャージ & 質量分析器 \\
\hline 山田, 2009 & 6061,7075 & 湿潤環境中での変形 & ガスクロマトグラフ（Arガス） \\
\hline 鈴木, $2010^{31)}$ & $2 \mathrm{~N}-\mathrm{Al}$ & 電解チャージ & ガスクロマトグラフ（Arガス） \\
\hline 鹿川, 2010 & $4 \mathrm{~N}-\mathrm{Al}$ & 湿潤環境，水中 & 質量分析器 \\
\hline Izumi, 2011 29$)$ & $4 \mathrm{~N}-\mathrm{Al}$ & 製造時添加 & 質量分析器 \\
\hline Kamoutsi, $2014^{40)}$ & 2024 & 腐食 & ガスクロマトグラフ（ $\mathrm{N}_{2}$ ガス） \\
\hline Bhuiyan, 2016 $6^{41), 42)}$ & 7000 系 & 製造時添加 & 質量分析器 \\
\hline 堀川, 2016 $6^{43) \sim 45)}$ & 6061,7075 & 製造時 & 半導体センサガスクロマトグラフ (Arガス) \\
\hline
\end{tabular}




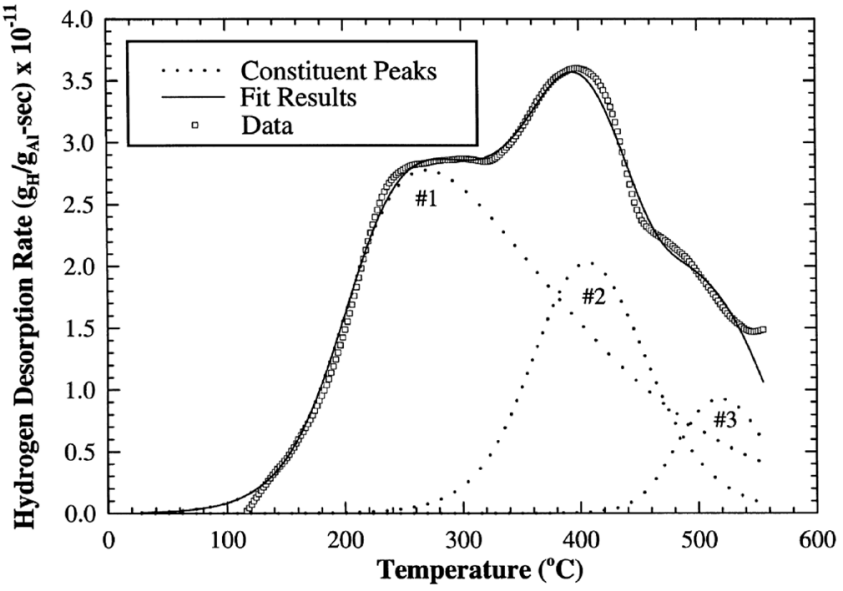

図3 Young ${ }^{28)}$ による高純度 $\mathrm{Al}$ に対する水素放出プ ロファイル

重極質量分析器により水素を検出して図3に示す水素放出プ ロファイルを得た。試料中の水素量の記載はない。2 250,400 , $500^{\circ} \mathrm{C}$ に現れた放出ピークを，それぞれ水素の拡散によるも の, 加工の有無の材料の結果の比較から転位にトラップさ れた水素によるもの, 過去の報告の結合エネルギーとの比 較から空孔にトラップされた水素によるものとし，トラッ プからの脱離の活性化エネルギーを $15.3,43.5,84.8 \mathrm{~kJ} / \mathrm{mol}$ と し，転位，空孔については水素との結合エネルギーを 27.3, $68.6 \mathrm{~kJ} / \mathrm{mol}$ と報告した。同じグループの Smith ら $^{30)}$ は電解水 素チャージにより水素添加した $\mathrm{Al}-\mathrm{Li}$ 合金を試料として水素 放出プロファイルを測定し, トラップサイトの同定を行っ た。

Izumi ら ${ }^{29)}$ は製造時に0.82 mass ppmの水素を添加した純 度 $4 \mathrm{~N}$ の厚さ $110 \mu \mathrm{m}$ の $\mathrm{Al}$ 箔を試料として, 高真空中におい て $480^{\circ} \mathrm{C} / \mathrm{h}$ の一定速度で昇温し, 四重極質量分析器により水 素を検出して図4に示す $200,390,490^{\circ} \mathrm{C}$ に放出ピークが見ら れる水素放出プロファイルを測定し, 各ピークに対応したト ラップサイトの結合エネルギーを評価した。それぞれの值 は20.0, 47.3, 76.3 kJ/molである。各ピークに対応するトラッ プサイトは, $200^{\circ} \mathrm{C}$ は空孔-水素対の試料中での拡散に関す る考察から空孔, $390^{\circ} \mathrm{C}$ はトラップサイトに関する消去法か ら転位, $490^{\circ} \mathrm{C}$ はブリスター量の異なる試料による結果の違 いからブリスターにトラップされた水素によるものと結論し た。

著者ら ${ }^{31)}$ は電解水素チャージにより水素添加した純度 $99 \%$ の厚さ $1 \mathrm{~mm}$ の $\mathrm{Al}$ 板を試料として, 常圧の高純度 $\mathrm{Ar}$ 中に おいて $200^{\circ} \mathrm{C} / \mathrm{h} の 一$ 定速度で昇温し, 放出される水素をガス クロマトグラフで測定して水素放出プロファイルを得た。添 加水素量は 10〜20 mass ppm と Young らおよびIzumiの報告と 比較して多く, 水素放出プロファイルはこれらの報告とは異 なり，室温付近に強いピークを示した。焼鈍した試料による 水素放出プロファイルを基準として，引張変形を加えて転位 の量を増やした試料，これに $200^{\circ} \mathrm{C} の$ 焼鈍を加えて転位を残 し，塑性変形に伴って生じた複空孔を焼失させた試料の水素 放出プロファイルを比較することにより, $60^{\circ} \mathrm{C}$ 付近の放出 ピークは転位にトラップされた水素, $90^{\circ} \mathrm{C}$ 付近のそれを複 空孔にトラップされた水素によるものとした。活性化エネル ギーの決定は行っていない。これらの水素放出プロファイル

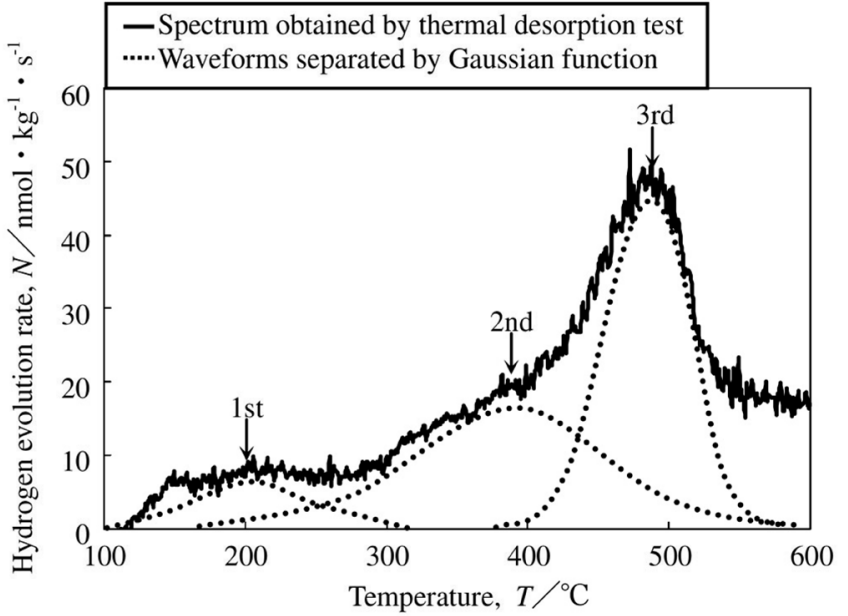

図4 Izumi ら ${ }^{29)}$ による高純度 $\mathrm{Al}$ に対する水素放出プロ ファイル

上の低温側の放出ピークに対応する水素は極めて不安定であ り, 室温での1〜3日の放置によりほとんど外部に放出され るとともに，材料内部のより安定なトラップ位置に移動する と考えた ${ }^{32)}$ 。電解チャージにより水素を添加した $5 \mathrm{~N}-\mathrm{Al} に$ 対して昇温速度を変えた昇温脱離試験を行い, ピーク位置の 変化から活性化エネルギーを求めたところ, $8.6 \mathrm{~kJ} / \mathrm{mol}$ となっ た ${ }^{33)}$ 。この值は本稿の後半で説明する榎本らによる第一原 理計算の結果では, 粒界との水素の結合エネルギーの範囲に 含まれる。これらの水素は試料表面近傍に存在していると 予測されるが, Lafouresseら ${ }^{34)}$ はケルビン力顕微鏡により電 解チャージした2024合金材の表面近傍の電位変化を測定し, その結果から, 水素吸蔵に伴って表面から数百 $\mu \mathrm{m}$ まで表面 からの距離に比例した量の水素が侵入し, その後の室温での 24〜48hの放置によりほぼ放出されることを示した。また同 じグループの Ogerら ${ }^{35)}$ は低 $\mathrm{Cu}$ の7000系 $\mathrm{Al}$ 合金に対して同 様の測定を行い, 表面近傍に見られる粒界割れの幅と水素の 侵入深さの比較から, これらの水素は粒界にトラップされて いると推測している。このような新しい技術により, 水素の トラップ挙動についての理解が進むことが期待される。

その他, 広畑ら ${ }^{36)}$ は $4 \mathrm{~N}-\mathrm{Al}$ (1001材) に対して高真空中 で加熱して質量分析器により測定した水素放出プロファイル を報告している。水素の拡散と材料表面からの脱離の機構を 中心に検討し, $600^{\circ} \mathrm{C} / \mathrm{h}$ で加熱した際に見られる $435^{\circ} \mathrm{C}$ 付近 の放出ピークは水素の拡散によるものであること, それより も低い温度に現れる肩状のピークは表面からの脱離によるも のであり, 表面酸化層の状態が脱離スペクトルに大きな影響 を及ぼすことを示した。

Hayashi $^{37)}$ は単結晶 $6 \mathrm{~N}-\mathrm{Al}$ およびAl-1000 ppmSiに対して水 中で研磨することで水素を添加し, 高真空中で加熱して質量 分析器により測定した水素放出プロファイルを報告してい る。この曲線では, $600^{\circ} \mathrm{C} / \mathrm{h}$ で加熱した時に $180^{\circ} \mathrm{C}$ 付近に顕 著なピークが見られる。

山田ら ${ }^{38)}$ は湿潤環境中で最大荷重点付近まで予備変形を 加えることで水素を侵入させた 6061 および7075Al合金に対 して, 常圧の高純度 $\mathrm{Ar}$ 中において $100^{\circ} \mathrm{C} / \mathrm{h}$ の一定速度で昇温 し, 放出される水素をガスクロマトグラフで測定して水素放 出プロファイルを測定した。いずれの試料でも $400^{\circ} \mathrm{C}$ 以上に 
顕著な放出ピークが見られる。

鹿川ら ${ }^{39)}$ は，4N-Alに対し，湿潤大気環境あるいは水中 に暴露して水素を吸蔵させ，高真空中で昇温し，放出される 水素を質量分析器により測定して $443^{\circ} \mathrm{C}$ おび $560^{\circ} \mathrm{C} に$ 放出 ピークが見られる水素放出プロファイルを測定した。過去の 報告での結果と対応させて，それぞれを転位とポアにトラッ プされた水素によるものと推定した。

Kamoutsi ${ }^{40)}$ は腐食により水素吸蔵した $\mathrm{Al}$ 合金2024を窒

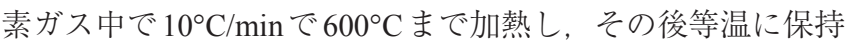

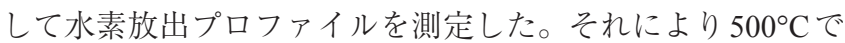
の放出ピークは析出物あるいは空孔, $400^{\circ} \mathrm{C} て ゙ の$ 放出ピーク は転位にそれぞれトラップされた水素によるものとした。

Bhuiyan ら ${ }^{41), 42)}$ は製造時に水素を添加した7000系 $\mathrm{A} 1$ 合金 に対して昇温脱離試験を行って水素放出プロファイルを測定 し，209, 311, $411^{\circ} \mathrm{C}$ に放出ピークを確認した。Izumiらの報 告のピーク温度との対比により，それぞれを空孔，転位，ミ クロポアにトラップされた水素によるものとして, 昇温速度 を変えた試験によりそれぞれの欠陥の水素との結合エネル ギーを 22.7, $50.1,131.7 \mathrm{~kJ} / \mathrm{mol}$ と求めた。また，X線 $\mu$-CTによ るミクロポアの直接観察の結果等により各種欠陥にトラップ された水素の割合を見積もり，水素量に依存してミクロポア または転位が主たる水素のトラップサイトであるとした。

堀川は7075 合金材 ${ }^{43)}, \mathrm{Fe}$ 量の異なる6061 合金材 ${ }^{44)}$, 高速 変形させた 6061 および7075 合金材 ${ }^{45)}$ を高純度の Arガス中 に拈いて一定速度で昇温し，放出される水素を高感度の半導 体センサを用いたガスクロマトグラフにより測定して水素 放出プロファイルを得た。いずれの材料に拈いても水素は $200^{\circ} \mathrm{C}$ 付近から放出が始まり, $500^{\circ} \mathrm{C}$ 付近以上で放出速度が ほぼ一定となる放出特性を示した。 $500^{\circ} \mathrm{C}$ 以上の水素放出は マイクロポアにトラップされていた水素によるものと推測し ている。

水素放出プロファイルに見られるピークをトラップサイト に結び付けることは，結合エネルギーの值が確定していなけ れば，加工や焼鈍等によってトラップサイトの性質や量を変 えた試料による結果を測定し，その違いを比較した結果に基 づく推定により行われるべきであろう。しかしながら，以 上の $\mathrm{Al}$ に対する昇温脱離試験の測定結果の報告においては, 次節で示す，測定結果や計算による結合エネルギーの值が比 較的揃っている空孔を同定する場合を除けば，そのような検 討を実際に行った報告例は少数しかなく，過去の報告との ピーク温度の比較に頼っていることがほとんどである。

異なるアプローチとして, 数值的に水素放出プロファイル をシミュレートして実験結果と比較し，検証することが行わ れるようになった ${ }^{61)}$ 。材料中の水素の拡散を拡散方程式に トラップの効果を加えた McNabb-Foster方程式 ${ }^{46)}$ や拡張し

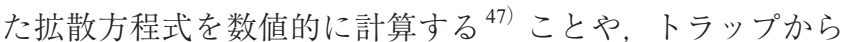
の熱脱離を仮定しない熱脱離方程式を数值的に計算すること により ${ }^{48)}$ ，水素放出プロファイルを再現し，トラップサイ トの結合エネルギー等のパラメータとの依存性を見ることに より，曲線上のピークとトラップサイトの対応が検証可能で ある。海老原ら ${ }^{49)}$ はY Young らやIzumiらの結果について検証 を行い，これらの報告でのピークとトラップサイトとの関係 には検討の余地があることを指摘している。このような手法 による検討がより進むことが望まれる。

\section{5. 水素と空孔の結合エネルギー}

$\mathrm{Al}$ においては種々のトラップサイトに対する水素の結合 エネルギーの信頼できる報告が少なく，それをまとめた例も ないが，空孔については比較的多くの実験結果と計算科学的 手法による值が報告されている。これを表 2 に発表順にまと めて示す。Myersら ${ }^{50)}$ は $5 \mathrm{~N}-\mathrm{Al}$ にイオン注入法により重水素 を添加し, 結合エネルギーを $50.1 \mathrm{~kJ} / \mathrm{mol}$ と求めた。Linderoth

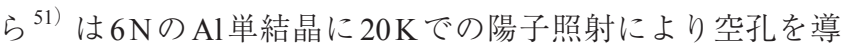
入し, 陽電子消滅寿命測定により結合エネルギーを $51.1 \mathrm{~kJ} /$ mol と測定した。Birnbaum ら ${ }^{14)}$ は, $5 \mathrm{~N}-\mathrm{Al} に$ 対して, 電気化 学的方法, 化学的方法, 超音波により 1000〜2000 appm 程度 の水素添加を行い, 結合エネルギーを $46.1 \mathrm{~kJ} / \mathrm{mol}$ と見積もっ た。Bhuiyan ら ${ }^{41), 42)}$ は製造時に水素を添加した7000系 $\mathrm{A} 1$ 合 金の水素放出プロファイル上の $209^{\circ} \mathrm{C}$ の放出ピークを空孔に よるものとし，結合エネルギーを $22.7 \mathrm{~kJ} / \mathrm{mol}$ と測定した。

計算により求めた例では, Wolverton ${ }^{52)}$ は結合エネル ギーを $31.8 \mathrm{~kJ} / \mathrm{mol}$ と求め, 水素の移動エネルギーを計算し て，空孔は拡散について強いバリアとなることを示した。 $\mathrm{Lu} 5^{53)}$ は空孔の結合エネルギーを $38.6 \mathrm{~kJ} / \mathrm{mol}$ と求めた。彼 らはまた空孔1つ当たり12 個までの水素原子が安定に存在し うるとしたが，これには異論がある ${ }^{62)} 。 \mathrm{Ji} ら^{54)}$ は結合エネ ルギーを $32.8 \mathrm{~kJ} / \mathrm{mol}$ と求めた。また， 1 空孔に $2 つ の$ 水素が 結合した場合のエネルギーは $67.5 \mathrm{~kJ} / \mathrm{mol}$ と高く, 高濃度の $\mathrm{H}$ 環境では 1 空孔-2 水素対の方が支配的となることを示した。 榎本ら ${ }^{55)}$ は次節に詳細を示すが，一連の第一原理計算によ る $\mathrm{Al}$ 中の欠陥と水素の結合エネルギーの計算のなかで, 空 孔の結合エネルギーを $28.9 \mathrm{~kJ} / \mathrm{mol}$ とした。Guanydin ${ }^{56)}$ は, 第一原理計算により $650 \mathrm{~K}$ から $850 \mathrm{~K}$ での $\mathrm{Al}$ 中の水素の拡散 係数を求め, 空孔が多数の水素と結合しうることから, 水素 の拡散を遅らせることを見出した。空孔と水素の結合エネル ギーを $48.2 \mathrm{~kJ} / \mathrm{mol}$ と見積もっている。この值はBesenbacher $ら^{57)}$ がイオン注入法により求め, fcc 金属に対する值とした ものである。Ishikawa ${ }^{58)}$ が高純度の $\mathrm{Al}$ に電気化学的方法 により水素添加した実験により同様の值を報告している。

福田ら ${ }^{59)}$ は第一原理計算により $\mathrm{Al}-\mathrm{Mg}-\mathrm{Zn}$ 系合金の結晶

表 2 空孔と水素の結合エネルギーの報告のまとめ

\begin{tabular}{|c|c|c|}
\hline 報告 & 方法（材料） & $\begin{array}{c}\text { 結合エネルギー } \\
(\mathrm{kJ} / \mathrm{mol})\end{array}$ \\
\hline Myers, $1985^{50)}$ & 実験（5 N-Al） & 50.1 \\
\hline Linderoth, $1987^{51)}$ & 実験（6N-Al） & 51.1 \\
\hline Birnbaum, 1997 ${ }^{14)}$ & 実験（5N-Al） & 46.1 \\
\hline Young, $1998^{28)}$ & 実験（5N-Al） & 64.7 \\
\hline Wolverton, $2004^{52)}$ & 第一原理計算 & 31.8 \\
\hline $\mathrm{Lu}, 2005^{53)}$ & 第一原理計算 & 38.6 \\
\hline Guanydin, $2008^{56)}$ & 第一原理計算 & 48.2 \\
\hline $\mathrm{Ji}, 2010^{54)}$ & 第一原理計算 & 32.8 \\
\hline 榎本, $2010^{55)}$ & 第一原理計算 & 28.9 \\
\hline Izumi, $2011^{29)}$ & 実験（4N-Al） & 20.0 \\
\hline 福田, 2014 & 第一原理計算 & 32.8 \\
\hline Bhuiyan, $2016^{41), 42)}$ & 実験（7000系 Al） & 22.7 \\
\hline
\end{tabular}


粒界の水素脆性を評価した。空孔と水素の結合エネルギーを $32.8 \mathrm{~kJ} / \mathrm{mol}$ と求めている。

これらの実験と計算による結果を比較すると，第一原理計 算による值はほぼ $30 \mathrm{~kJ} / \mathrm{mol}$ 前後で一致しているが，実験に よる報告はばらつきが大きく、計算による值よりもかなり大 きい。

\section{6. 計算科学による水素と欠陥の結合エネルギーの 評価}

実験的に求まった $\mathrm{Al}$ 中の水素と欠陥の結合エネルギーの 信頼できる報告が少ない状態では, 近年著しく発達した計 算科学的手法により, これらの值を定めることが期待され る。先ほどまとめた空孔と水素の結合エネルギー中の，第一 原理計算による結果が一例である。榎本ら ${ }^{55)}$, 60) は第一原理 計算により $\mathrm{Al}$ 中の原子空孔，積層欠陥，粒界，自由表面な どの格子久陥と水素の結合エネルギーを統一的に計算した結 果を報告している。表了に久陥の次元の順に並べた結合エネ

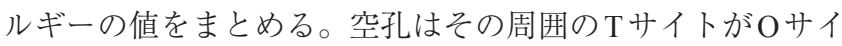
トや原子空孔サイトと比較して安定であり, 結合エネルギー は $28.9 \mathrm{~kJ} / \mathrm{mol}$ である。らせん転位の中心に最も近い $\mathrm{T}$ サイト で，水素は最も安定であるが，結合エネルギーは $-1.0 \mathrm{~kJ} / \mathrm{mol}$ であり，水素はトラップされにくい。刃状転位でも転位中 心に最も近い $\mathrm{T}$ サイトで水素は最も安定であり, 結合エネル ギーは $13.5 \mathrm{~kJ} / \mathrm{mol}$ である。積層欠陌近傍の Oサイトで水素は 安定であるが, 結合エネルギーは0であり, 積層欠陥と水素 の相互作用は小さいことがわかる。結晶粒界は安定な粒界と 比較的ランダムな 2 種の高エネルギー粒界について, 粒界周 りの局所安定位置に水素を導入し，それぞれの結合エネル ギーを得ている。また，自由表面についても $\mathrm{Al}$ の割れ面に ついて結合エネルギーを計算している。 $\mathrm{Al}\{111\} / \mathrm{Si}\{100\}$ 界面 では界面中に複数の水素がほぼ同じ溶解熱で存在でき, 結合 エネルギーは $37.6 \mathrm{~kJ} / \mathrm{mol}$ である。また $\mathrm{Al}\{111\}$ と $\mathrm{MoPt}_{2}$ 型の $\mathrm{Mg}_{2} \mathrm{Si}\{110\}$ 界面に対する結合エネルギーは $\mathrm{Mg}_{2} \mathrm{Si}$ 側の界面近 傍が最も安定であり, $18.3 \mathrm{~kJ} / \mathrm{mol}$ である。

表 3 榎本ら ${ }^{55), 60)}$ の第一原理計算による久陥と水素の 結合エネルギー

\begin{tabular}{l|c|c}
\hline \hline \multicolumn{2}{c|}{ 欠陥 } & 結合エネルギー $(\mathrm{kJ} / \mathrm{mol})$ \\
\hline 空孔 & Tサイト & 28.9 \\
\hline 刃状転位 & & 13.5 \\
\hline らせん転位 & & -1.0 \\
\hline 積層欠陥 & Oサイト & 0.0 \\
\hline 粒界 & $\Sigma 3\{111\}$ & 1.9 \\
& $\Sigma 3\{112\}$ & 18.3 \\
& $\Sigma 19\{331\}$ & 23.2 \\
\hline 自由表面 & $\{111\}$ & 76.2 \\
& $\{110\}$ & 86.9 \\
& $\{110\}$ & 90.8 \\
\hline $\mathrm{Al} / \mathrm{Si}$ 界面 & & 37.6 \\
\hline $\mathrm{Al} / \mathrm{Mg}_{2} \mathrm{Si}$ 界面 & & 18.3 \\
\hline
\end{tabular}

\section{7. ま と め}

$\mathrm{Al}$ を中とした金属材料中の水素トラップ挙動について, これまでの知見や報告をまとめた。

（1） $\mathrm{A} 1$ 中の水素のトラップサイトとしては，固溶，転位， 水和酸化被膜, 酸化被膜/金属界面, 結晶粒界, ポロシティ, 第二相内，第二相／母相界面，ナノボイドが考えられる。

(2) 昇温脱離試験により得られる水素放出プロファイル 中に現れる水素放出ピークを解析することによりトラップサ イトを同定し，また水素とトラップサイトとの結合エネル ギーを求めることが鉄鋼材料を中心に広く行われている。 $\mathrm{Al}$ についても多くの報告があるが, 試験方法や試験結果の解釈 についてはいまだ検討の余地がある。

（3） $\mathrm{Al}$ 中の水素と欠陥の結合エネルギーについてはあま りデータがないが, 水素と空孔の結合エネルギーについては 実験結果と計算科学的手法による值が比較的多く報告されて おり, 後者は $30 \mathrm{~kJ} / \mathrm{mol}$ 前後の值が多いが, 前者については それよりも大きな值が多く，報告間のばらつきも大きい。

（4）計算科学により多様な欠陥での水素と欠陥の結合工 ネルギーを評価した例は少ないが，今後の報告の増加と精度 および信頼性の向上が期待される。

\section{参 考 文 献}

1）南雲道彦：水素脆性の基礎，内田老鶴戋，（2008）

2) 哚井 有, 田中一英, 内田裕久: 水素と金属, 内田老鶴 围, (1998)。

3) J. P. Hirth: Met. Trans. A, 11A (1980), 861-890,

4) Ch. A. Wert: Hydrogen in Metals II, G. Alefeld and J. Volkl (Eds.), (1978), 305-330.

5) K. Christmann: Surf. Sci. Rep., 9 (1988), 1-163.

6) 横川清志：水素エネルギーシステム，4 (2016)，259-268.

7) 深井有, 田中一英, 内田裕久: 水素と金属, 内田老鶴 戋, (1998)，65-69.

8）南雲道彦：水素脆性の基礎，内田老鶴圃，（2008），19-47.

9）伊藤吾朗，菅野幹宏：金属，66（1996）, 599-610.

10) S. W. Smith and J. R. Scully: Metall. Trans. A, 31A (2000), 179-193.

11) M. Ichimura, Y. Sasajima and M. Imabayashi: Mater. Trans., 32 (1991), 1109-1114.

12) K. R. Hebert: Electrochim. Acta, 168 (2015), 199-205.

13) E. Hashimoto and T. Kino: J. Phys. F, 13 (1983), 1157-1165.

14) H. K. Birnbaum, C. Buckley, F. Zeides, E. Sironis, P. Rozenak, S. Spooner and J. S. Lin: J. Alloys Compd., 253-254 (1997), 260-264.

15) C. E. Buckley, H. K. Birnbaum, J. S. Lin, S. Spooner, D. Bellmann, P. Staron, T. J. Udovic and E. Hollar: J. Appl. Cryst., 34 (2001), 119129.

16) G. M. Scammans: J. Mater. Sci., 13 (1978), 27-36.

17) M. Paskevicius and C. E. Buckley: J. Appl. Cryst., 39 (2006), 676682.

18) D. Tanguy and M. Mareschal: Phys. Rev. B, 72 (2005), 174116.

19) S. Adhikari, J. H. Ai, K. R. Hebert, K. M. Ho and C. Z. Wang: Electrochim. Acta, 55 (2010), 5326-5331.

20）堀川敬太郎，外䓟俊輔，小林秀敏：軽金属，66 (2016), 77-83.

21) H. Toda, H. Hidaka, M. Kobayashi, K. Uesugi, A. Tanaka and K. Horikawa: Acta Mater., 57 (2009), 2277-2290.

22) G. Itoh, K. Koyama and M. Kanno: Scr. Mater., 35 (1996), 695-698.

23）堀川敬太郎, 竹内祐介, 吉田憲一, 小林秀敏：軽金属, 56 (2006), 210-213.

24) K. Verbeken: Gaseous Hydrogen Embrittlement of Materials in Energy Technologies (R.P. Gangloff and B.P. Somerday Eds.), (2012), 27-55. https://doi.org/10.1533/9780857095374.1.27.

25) W. Y. Choo and J. Y. Lee: Metall. Trans. A, 13A (1982), 130-142.

26) K. Takai, H. Shoda, H. Suzuki and M. Nagumo: Acta Mater., 56 (2008), 5158-5167. 
27) 今野良佑, 真鍋敏之, 平上大輔, 高井健一：鐵と鋼, 104 (2018), 36-45

28) G. A. Young Jr. and J. R. Scully: Acta Mater., 46 (1998), 6337-6349.

29) T. Izumi and G. Itoh: Mater. Trans., 52 (2011), 130-134.

30) S. W. Smith and J. R. Scully: Metall. Trans. A, 31A (2000), 179-193.

31）鈴木啓史，小林大輔，花田信子，高井健一，萩原行人：日本金 属学会誌, 74 (2010), 65-71。

32) H. Suzuki, K. Takai and M. Fujinami: PRiME 2012, Hawaii, USA, Oct. 7-12, 2012.

33) 鈴木, 未発表デー夕.

34) M. C. Lafouresse, M.-L. de Bonfils-Lahovary, C. Charvillat, L. Oger, L. Laffont and C. Blanc: J. Alloys Compd., 722 (2017), 760-766.

35) L. Oger, M. C. Lafouresse, G. Odemer, L. Peguet and C. Blanc: Mater. Sci. Eng. A, 760 (2017), 126-135.

36) 広畑優子, 藤元 哲, 日野友明, 山科俊郎: 北海道大学工学部 研究報告, No. 159,(1992), 31-46.

37) S. Hayashi: Jpn. J. Appl. Phys., 37 (1998), 930-937.

38) 山田浩之, 堀川敬太郎, 谷垣健一, 小林秀敏：日本機械学会論 文集（A 編），75（2009），1630-1638。

39）鹿川隆廣, 伊藤吾朗：軽金属, 60 (2010), 433-437.

40) H. Kamoutsi, G.N. Haidemenopoulos, V. Bontozoglou, P.V. Petroyiannis and Sp.G. Pantelakis: Corros. Sci., 80 (2014), 139-142.

41) Md. S. Bhuiyan, H. Toda, Z. Peng, S. Hang, K. Horikawa, K. Uesugi, A. Takeuchi, N. Sakaguchi and Y. Watanabe: N.: Sakaguchi and Y. Watanabe: Mater. Sci. Eng. A, 655 (2016), 221-228.

42) Md. S. Bhuyian, H. Toda, Z. Peng, S. Hang, K. Horikawa, K. Uesugi and A. Takeuchi: N.: Sakaguchi and Y. Watanabe: Mater. Sci. Eng. A, 668 (2016), 271-272.

43 ）堀川敬太郎, 外薗俊輔, 小林秀敏：軽金属, 66（2016）, 77-83.

44) 堀川敬太郎, 高橋優花, 小林秀敏：66 (2016), 84-89.

45) 堀川敬太郎, 小椋 智, 遠藤 剛, 高橋 誠, 小林秀敏：軽金
属, 66 (2016), 90-95.

46) A. McNabb and P. K. Foster: Trans. Metall. Soc. AIME, 227 (1963), $618-627$.

47) T. Yamaguchi and M. Nagumo: ISIJ Int., 43 (2003), 514-519.

48) K. Ebihara and H. Kaburaki: ISIJ Int., 52 (2012), 181-186.

49) 海老原健一, 山口正剛, 都留智仁, 板倉充洋 : 軽金属学会第 131 回秋期大会講演概要, (2016)，271-272.

50) S. M. Myers, F. Besenbacher and J. K. Norskov: J. Appl. Phys., 58 (1985), 1841-1850.

51) S. Linderoth, H. Rajainmaki and R. M. Nieminen: Phys. Rev. B, 35 (1987), 5524-5528.

52) C. Wolverton, V. Ozolins and M. Asta: Phys. Rev. B, 69 (2004), 144109.

53) G. Lu and E. Kaxiras: Phys. Rev. Lett., 94 (2005), 155501.

54) M. Ji, C. Wang, K. Ho, S. Adhikari and K. R. Hebert: Phys. Rev. B, 81 (2010), 024105.

55）榎本龍博, 松本龍介, 武富紳也, 宮崎則之：材料, 59（2010）, 596-603.

56) H. Gunaydin, S. V. Barabash, K. N. Houk and V. Ozolins: Phys. Rev. Lett., 101 (2008), 075901.

57) F. Besenbacher, S. M. Myers and J. K. Norkov: Nucl. Instrum. Methods Phys. Res., B718 (1985), 55-66.

58) T. Ishikawa and R. B. McLellan: Acta Metall., 34 (1986), 1091-1095.

59) 福田忠生, 小武内清貴, 尾崎公一, 北浦宏将, 田辺晃弘: 材料, 63 (2014), 174-181.

60) R. Matsumoto, T. Enomoto, S. Taketomi and N. Miyazaki: IHC2012, Wyoming, U.S.A., 9-12 Sep. 2012.

61) 海老原健一：まてりあ, 57 (2018), 338-344.

62) L. Ismer, M. L. Park, A. Janotti and C. G. Van de Walle: Phys. Rev. B, 80 (2009), 184110. 